\title{
Temporal and spatial variations in the parasitoid complex of the horse chestnut leafminer during its invasion of Europe
}

\author{
Giselher Grabenweger • Patrik Kehrli • Irene Zweimüller - Sylvie Augustin • \\ Nikolaos Avtzis • Sven Bacher • Jona Freise • Sandrine Girardoz • \\ Sylvain Guichard • Werner Heitland • Christa Lethmayer • Michaela Stolz • \\ Rumen Tomov $\cdot$ Lubomir Volter $\cdot$ Marc Kenis
}

\begin{abstract}
The enemy release hypothesis posits that the initial success of invasive species depends on the scarcity and poor adaptation of native natural enemies such as predators and parasitoids. As for parasitoids, invading hosts are first attacked at low rates by a species-poor complex of mainly generalist species. Over the years, however, parasitoid richness may increase either because the invading host continuously
\end{abstract}

Electronic supplementary material The online version of this article contains supplementary material

G. Grabenweger · M. Stolz

BOKU Vienna, Institute of Plant Protection, Peter Jordan Straße 82, 1190 Vienna, Austria

Present Address:

G. Grabenweger $(\bowtie) \cdot$ C. Lethmayer

AGES Vienna, Spargelfeldstraße 191, 1226 Vienna,

Austria

e-mail: giselher.grabenweger@ages.at

P. Kehrli · S. Bacher

UNI Bern, Institute of Zoology, Baltzerstraße 3,

3012 Bern, Switzerland

Present Address:

P. Kehrli

Service Entomologie, Station de Recherche Agroscope

Changins-Wädenswil, 1260 Nyon, Switzerland

I. Zweimüller

Faculty of Life Sciences, University of Vienna,

Althanstr. 14, 1090 Vienna, Austria encounters new parasitoid species during its spread (geographic spread-hypothesis) or because local parasitoids need different periods of time to adapt to the novel host (adjustment-hypothesis). Both scenarios should result in a continuous increase of parasitoid richness over time. In this study, we reconstructed the development of the hymenopteran parasitoid complex of the invasive leafminer Cameraria ohridella (Lepidoptera, Gracillariidae). Our results show that the overall parasitism rate increases as a function of host residence time as well as geographic and climatic factors, altogether reflecting the historic spread of

S. Augustin $\cdot$ S. Guichard

INRA Orleans, UR633 Zoologie Forestière, CS 40001 Ardon, 45075 Orléans, France

N. Avtzis

Department of Forestry, TEI Kavala, Proastio, 66100 Drama, Greece

Present Address:

S. Bacher

UNI Fribourg, Department of Biology, Chemin du Musée 10, 1700 Fribourg, Switzerland

J. Freise $\cdot$ W. Heitland

Department of Animal Ecology, TU Munich, Am

Hochanger 13, 85354 Freising, Germany

Present Address:

J. Freise

LAVES Niedersachsen, Postfach 3949, 26029 Oldenburg,

Germany 
C. ohridella. The same variables also explain the individual parasitism rates of several species in the parasitoid complex, but fail to explain the abundance of others. Evidence supporting the "geographic spread-hypothesis" was found in the parasitism pattern of Cirrospilus talitzkii (Hymenoptera, Eulophidae), while that of Pediobius saulius, another eulophid, indicated an increase of parasitism rates by behavioral, phenological or biological adjustments. Compared to fully integrated host-parasitoid associations, however, parasitism rates of $C$. ohridella are still very low. In addition, the parasitoid complex lacks specialists, provided that the species determined are valid and not complexes of cryptic (and presumably more specialized) species. Probably, the adjustment of specialist parasitoids requires more than a few decades, particularly to invaders which establish in ecological niches free of native hosts, thus eliminating any possibility of recruitment of pre-adapted parasitoids.

Keywords Parasitoid recruitment .

Adaptation - Host residence time .

Eulophidae · Gracillariidae

\section{Introduction}

The introduction and spread of non-native species is a global ecological and economical challenge because invasive organisms may alter species communities and ecosystem services provided (Gurevitch and Padilla 2004; Hooper et al. 2005). Hypotheses explaining the success of invaders are based upon ways in which exotic species' new ranges differ from their native ranges (Blumenthal 2005). The most straightforward and intuitively appealing explanations are that invasive organisms are more

\footnotetext{
S. Girardoz · M. Kenis

CABI Europe-Switzerland, 1Rue des Grillons, 2800 Delémont, Switzerland

R. Tomov

Faculty of Agronomy, University of Forestry, Bul. Kliment Ohridski 10, 1756, Sofia, Bulgaria

L. Volter

Institute of Entomology, Biology Centre of the Academy of Sciences, Branisovska 31, 37005 České Budějovice, Czech Republic
}

competitive than their native competitors (Callaway and Aschehoug 2000; Shea and Chesson 2002) and that they are released from the effects of their diseases and natural enemies (Keane and Crawley 2002; Mitchell and Power 2003). The enemy release hypothesis posits that the invasion success of these exotic species is related to the scarcity of antagonists, such as pathogens, parasites, parasitoids and predators, in the introduced range compared to their native range. On the one hand, the number of natural enemy species can be reduced in the introduced range (apparent enemy reduction) and on the other hand, the effect of these enemies on the invader can be lower (realized enemy release) (Torchin et al. 2003; Mitchell and Power 2003; Colautti et al. 2004). Natural enemies in the introduced range are therefore supposed to need time to adapt before they may succeed in reducing the ecological threats of a successful invader. The mechanisms involved in such adaptive processes are only partly understood, but of crucial importance in research on biological invasions and for the development of control measures. For studying these mechanisms, parasitoids are of particular interest because they develop, by definition, within or attached to a host organism, which implicates that they have mostly coevolved with their actual host species (Quicke 1997).

Cornell and Hawkins (1993) reviewed the literature on phytophagous insects and their parasitoids in native and invaded regions. They found evidence that invading hosts assembled poorer parasitoid complexes which generally exhibited lower levels of parasitism. Moreover, the ratio of idiobionts to koinobionts was much higher than those found in native host-parasitoid associations. Idiobiont parasitoids are mostly ectoparasitoids which consume their host "in the location and state it is in when attacked" (Askew and Shaw 1986). As a consequence of this rapid host death, these parasitoids do not need to adapt to the host's physiology, which allows them to exploit a broader host range and to switch to new hosts more easily. By contrast, koinobionts are mostly endoparasitoids that allow their host "to stay mobile, to continue to develop and to defend itself" (Askew and Shaw 1986). These parasitoids have to adapt to the physiology of the still-living host in order to overcome its internal defense mechanisms, which requires a higher degree of specialization and hence leads to a narrow host range. Accordingly, Cornell and Hawkins (1993) concluded 
that parasitoid complexes of invading hosts comprise more species with broad host ranges than those of native hosts. The adaptation of koinobiont specialists to invading hosts is expected to last longer. In addition, the authors found a weak yet significant increase of parasitoid richness as a function of host residence time and proposed two explanations: First, in the "adjustment-hypothesis", parasitoids may need a certain period of time for behavioral, phenological or biological adjustment to the new host species. The different periods of adjustment of the various parasitoid species would therefore lead to a continuous increase of parasitoid richness. Secondly, in the "geographic spread-hypothesis", the invading host may encounter new parasitoid species during its spread, thereby accumulating a broader complex of parasitoids. This accumulation may also result in a continuous increase of parasitoid richness over time. However, although the effect of host residence time on parasitoid richness was evident, the authors were not able to define the time period required until the parasitoid assemblage of an invader becomes indistinguishable from that of a native host. There was a weak indication that this process would at least require a period of 150 years, but may also last 10,000 years. Meanwhile, Godfray et al. (1995) analyzed the parasitoid recruitment of two leafminers roughly 10 years after they had invaded the British Islands from mainland Europe. Contrary to Cornell and Hawkins (1993), the parasitoid complexes of these invasive Phyllonorycter species were already identical to those of native leafminers with respect to species richness, idiobiont-koinobiont ratios and the host ranges of the parasitoid species. Presumably, the rapid adjustment of at least one of the koinobiont specialists was possible due to its existing pre-adaptations to the ecological niche inhabited by the invader.

In the present study, we evaluated the relevance of the geographic spread-hypothesis and the adjustmenthypothesis for the invasion of the European continent by the horse chestnut leafminer, Cameraria ohridella Deschka and Dimic (Lepidoptera, Gracillariidae), which started in the early 1980s. Larvae of C. ohridella mine the leaves of the white flowering horse chestnut (Aesculus hippocastanum L., Hippocastanaceae), causing severe damage to this important shade and amenity tree (Heitland et al. 1999; Thalmann et al. 2003). The invasion of Europe by $C$. ohridella occurred in two main waves. The first wave started in the late 1970s from the Lake Ohrid in the Balkans
(Simova-Tošić and Filev 1985), where C. ohridella was first detected (Deschka and Dimic 1986). The leafminer spread to all neighbouring regions in southeast Europe with an average speed of 50$100 \mathrm{~km}$ per year (Šefrová and Laštůvka 2001; Heitland et al. 2005). The second wave was probably triggered by accidental introductions of leafminers by human traffic and transport. The most important was that to Upper Austria in 1989 (Puchberger 1995). From there, C. ohridella invaded central, western and northern Europe. Around 1993, the two waves of spread met in Croatia and southern Hungary. Maps visualizing the spread of $C$. ohridella are given in Šefrová and Laštůvka (2001), Tomiczek and Krehan (1998) and Gilbert et al. (2004, 2005).

The origin of $C$. ohridella has always been a matter of debate (Deschka and Dimić 1986; Grabenweger and Grill 2000; Grabenweger et al. 2005a; Hellrigl 2001; Holzschuh 1997; Kenis et al. 2005), with the Balkans, Asia, or north America as possible areas of origin. Accordingly, the age of the horse chestnut leafminer populations in the Balkans should be thousands if not millions of years in the first case, while it is a few decades maximum in the latter two cases. A non-European origin of $C$. ohridella is supported by (1) the absence of the leafminer until the late 1980s in planted horse chestnut stands in Europe, including southeastern Europe, despite the moth's high dispersal capacity (Gilbert et al. 2005) and the fact that its host tree has been planted as ornamental tree in Europe from the sixteenth century onwards, (2) unabated outbreaks of the leafminer populations since more than 20 years (Kenis et al. 2005), and (3) the lack of specialists in the leafminer's parasitoid complex and the exceptionally low parasitism rates throughout Europe, including natural stands in the Balkans. In all invaded areas, C. ohridella is attacked by a large number of native predators and parasitoids (e.g., Heitland et al. 1999; Hellrigl 2001; Grabenweger et al. 2005a, b), but so far these natural enemies do not regulate the population density of the leafminer (Girardoz et al. 2007a, b). By contrast, the Balkans as the origin of the horse chestnut leafminer are supported by the theory that the only representative of the genus Cameraria in Europe may be a relict species, which survived the glacial cooling of the tertiary period together with its main host tree, A. hippocastanum (Deschka and Dimić 1986; Grabenweger and Grill 2000; Xiang 
et al. 1998). This theory is more recently supported by a study based on mitochondrial and microsatellite DNA markers (Valade et al. 2009). High genetic diversity found in C. ohridella populations of remote natural horse-chestnut stands in the mountains of the southern Balkans suggest that $C$. ohridella is native to this region. However, genetic diversity was significantly lower in all populations collected in planted horse chestnut stands, including those in near vicinity to natural stands in the Balkans.

We studied the parasitoid complex of C. ohridella and assessed its parasitism rate over 3 years. Our study includes samples from populations close to the region of $C$. ohridella's first discovery and possible area of origin, with a presumably well preserved local parasitoid assemblage, as well as samples from populations situated several hundreds of kilometers apart, allowing for the encounter of potential parasitoid species from different climatic and ecological regions. The host residence times varied between one and at least 20 years. This implies that at former locations native parasitoids had a negligible period of time for adaptations to the novel host, whereas at the latter they had a minimum of two decades to adapt.

The main aims of the investigation were to:

- Reconstruct the development of C. ohridella's parasitoid complex over a large spatial as well as temporal scale.

- Identify any detectable signs of adaptation of the native parasitoid fauna, in particular the screen for koinobionts with a narrow host range that have adapted to the novel host during its spread within the last 20 years.

- Verify if parasitism rates and parasitoid richness are correlated with the age of the host populations or with other geographic and climatic parameters at the study sites.

\section{Materials and methods}

\section{Sampling}

Infested leaves of A. hippocastanum were collected at 70 locations in Europe from spring 2001 to autumn 2003. With the exception of six natural A. hippocastanum stands in southeast Europe, sampling locations were chosen with similar habitat parameters, i.e., parklike plantation with at least three horse chestnuts trees and a lawn or meadow beneath, partial leaf removal in autumn and presence of other trees and shrubs. One to four leaf samples were collected each year at the end of the respective leafminer generation, resulting in a total of 216 samples. Fifty leaves were randomly picked from the lower branches ( $<3 \mathrm{~m}$ height) of sampled horse chestnut trees. Leaflets were detached from the leaves and a minimum of 50 leaflets were randomly selected. A maximum of ten mines per leaflet was dissected under a stereomicroscope. The goal of at least 500 dissected mines was not always obtained in weakly infested samples. Overall, between 39 and 752 mines were examined with an average of 515 mines per sample. Preimaginal stages of the leafminer were determined during dissection after Freise and Heitland (2004) and abbreviated as follows: L1 to L4 = first to fourth larval instar (the latter including a rarely occurring fifth feeding instar), Sp1 and $\mathrm{Sp} 2=$ first and second spinning instars, $\mathrm{P}=$ pupa. Mines were characterized as not parasitized, parasitized or suspicious. Suspicious mines contained paralyzed or dead leafminer larvae. Pupae as well as parasitized and suspicious mines were isolated and individually maintained in small vials at room temperature to allow the emergence of potential parasitoids. After a minimum time period of 2 months, vials with the preserved mines and pupae were carefully examined and emerged parasitoids were sexed and determined according to Grabenweger et al. (2003). After dissection, the remaining leaves of each sample containing a variable number of intact mines were not discarded but kept in sealed bags for 2 months. These bags were checked visually for emerged parasitoids, in order to monitor eventual endoparasitic koinobionts emerging from larval stages, which might have been overlooked during dissections. Doubtful parasitoids were sent to the first author or to other parasitoid taxonomists (see list in the "Acknowledgments"). Voucher specimens are stored in the private collection of the corresponding author.

Data record

Each sampling location was characterized by its geographic coordinates, its altitude, the climate of its nearest meteorological station and the age of the C. ohridella population (details for all locations are given in the "Supplementary material"). Climate was specified by three parameters available for 60 locations: temperature range (calculated from the average 
winter minimum and the average summer maximum), the average annual temperature and the average annual precipitation. The age of the host population was determined as the number of years of presence since its first discovery at the sampling location. Accurate determination of the first appearance of $C$. ohridella in the Greek horse chestnut stands was impossible due to the lack of survey data. The age of these populations was therefore estimated to be similar to that of the nearest site with known host residence time, namely Lake Ohrid, where the leafminer was first discovered. However, analyses susceptible to a possible underestimation of the host residence time have been carried out twice, including and excluding Greek natural stands, to accommodate for the controversial discussion about the origin of C. ohridella.

The parasitism rate of $C$. ohridella was defined as the percentage of parasitized mines divided by the total number of mines dissected. This method does not allow for exact statements on total parasitism rates, yet it accounts for the problem of gregarious parasitoids and it is appropriate to compare parasitism levels of different locations. Host mortality due to host-feeding or host-stinging behaviour was not included into the analysis.

Additional parameters describing the parasitoid complex were (1) species richness $\mathrm{S}$, which was defined as the number of parasitoid species found per location, (2) the diversity index $H_{S}\left(H_{S}=-\sum \mathrm{p}_{\mathrm{i}(i=1-}\right.$ ${ }_{S)} \ln p_{i}, p_{i}=$ the proportion of species $i$ relative to the total number of species), (3) the evenness $E$ after Shannon and Wiener $\left(E=H_{S} / \ln S\right)$ (see Washington 1984) and (4) the percentage of reared female offspring as an indicator of host acceptance.

\section{Statistical analysis}

A cluster analysis was carried out, using the parasitoid species' proportions at the sampling locations as variables, to examine for regional differences in the parasitoid complex of $C$. ohridella. Samples were pooled for each collection site and all locations with more than 700 mines dissected and at least 15 parasitoid specimens reared in total were considered, resulting in a data set of 53 locations. Parasitoid species with less than ten individuals sampled over the whole study (16 out of 29 species in total) were considered to attack $C$. ohridella only occasionally and were therefore excluded from analysis. Squared Euclidian distances were used as distance measures and the Ward-method served as clustering algorithm.

Three principal component analyses (PCAs) were conducted to eliminate co-linearity and to obtain uncorrelated independent factors for regression analysis. The Kaiser criterium (eigenvalue $>1$ ) was used to determine the number of axes and varimax-rotation was applied to interpret the resulting PCA-axes. The first PCA was calculated on the parasitism rates of $C$. ohridella's preimaginal stages (L1-L3, L4, Sp1/2 and P) and the total parasitism rate. To avoid any influence of season, only samples of the leafminer's first generation collected between end of May and beginning of July were considered, resulting in a data set of 118 samples in total. The second PCA described the individual parasitism rates of the five most frequent parasitoid species. Samples with $<50 \%$ of the isolated mines producing adult (and identifiable) parasitoids were excluded from this analysis (93 samples remaining). A third PCA was performed with the environmental parameters recorded for each sample, including host residence time as well as the geographic and climatic parameters described previously. Then, linear regression analyses were conducted with the PCA-axes resulting from the third PCA as explanatory variables and the PCA-axes resulting from the first and second PCA as dependent variables. PCAs and regressions were repeated excluding data from Greek natural stands, where the age of the host population is unclear. Accounting for multiple testing, the significance values of the five regression analyses were Bonferroni-corrected.

Prior to statistical analysis, parasitism rates were arcsin-transformed and sea levels and geographic longitudes were log-transformed.

\section{Results}

Parasitoid complex of C. ohridella

Of the 111,190 mines dissected, 6,335 (5.7\%) were parasitized. Parasitoids successfully emerged out of $4,578(72.3 \%)$ parasitized mines. A total of 29 parasitoid species of five hymenopteran families were determined, most of them belonging to the chalcidoid family Eulophidae (Table 1; "Supplementary material"). Besides a majority of idiobiont parasitoids, the complex also comprised four koinobionts, none of 
Table 1 Parasitoid complex of C. ohridella in Europe

\begin{tabular}{|c|c|c|c|c|}
\hline & Abundance $(\%)$ & Location & $\begin{array}{l}\text { Life history } \\
\text { strategy }\end{array}$ & $\begin{array}{l}\text { Number of host } \\
\text { species }\end{array}$ \\
\hline \multicolumn{5}{|l|}{ Chalcidoidea } \\
\hline \multicolumn{5}{|l|}{ Eulophidae-Elachertinae } \\
\hline Cirrospilus diallus Walker & $<0.1$ & NW & Idiobiont & 51 \\
\hline C. elegantissimus westwood & $<0.1$ & SE & Idiobiont & 9 \\
\hline C. pictus (Nees) & $<0.1$ & NW & Idiobiont & 68 \\
\hline C. variegatus (Masi) & $<0.1$ & SE & Idiobiont & 17 \\
\hline C. viticola (Rondani) & 1.64 & SE & Idiobiont & 25 \\
\hline C. vittatus Walker & 0.17 & NW/SE & Idiobiont & 101 \\
\hline C. talitzkii Boucek & 0.22 & SE & Idiobiont & 11 \\
\hline Elachertus inunctus Nees & $<0.1$ & NW/SE & Koinobiont & 24 \\
\hline \multicolumn{5}{|l|}{ Eulophidae-Entedoninae } \\
\hline Chrysocharis nepherea (Walker) & 2.95 & NW/SE & Idiobiont & 119 \\
\hline C. pentheus (Walker) & $<0.1$ & SE & Idiobiont & 104 \\
\hline C. nitetis (Walker) & $<0.1$ & SE & Idiobiont & 40 \\
\hline C. phryne (Walker) & 0.26 & SE & Koinobiont & 23 \\
\hline Closterocerus lyonetiae (Ferriere) & $<0.1$ & SE & Idiobiont & 4 \\
\hline C. trifasciatus westwood & 6.42 & NW/SE & Idiobiont & 90 \\
\hline Neochrysocharis chlorogaster (Erdös) & 0.33 & NW/SE & Koinobiont & 17 \\
\hline Pediobius saulius (Walker) & 46.41 & NW/SE & Koinobiont & 62 \\
\hline \multicolumn{5}{|l|}{ Eulophidae-Eulophinae } \\
\hline Pnigalio mediterraneus (Ferr. and Del.) ${ }^{\mathrm{a}}$ & 8.7 & NW/SE & Idiobiont & 41 \\
\hline P. pectinicornis (L.) & 0.37 & NW/SE & Idiobiont & 88 \\
\hline P. soemius (Walker) & $<0.1$ & NW & Idiobiont & 86 \\
\hline Hemiptarsenus ornatus (Nees) & $<0.1$ & NW & Idiobiont & 17 \\
\hline Sympiesis sericeicornis (Nees) & 0.17 & NW/SE & Idiobiont & 123 \\
\hline \multicolumn{5}{|l|}{ Eulophidae-Tetrastichinae } \\
\hline Baryscapus nigroviolaceus (Nees) & 1.46 & $\mathrm{NW} / \mathrm{SE}$ & Idiobiont & 21 \\
\hline Minotetrastichus frontalis (Nees) & 30.54 & NW/SE & Idiobiont & 52 \\
\hline \multicolumn{5}{|l|}{ Eupelmidae } \\
\hline Eupelmus urozonus Dalman & 0.15 & NW/SE & Idiobiont & 103 \\
\hline \multicolumn{5}{|l|}{ Pteromalidae } \\
\hline Pteromalus semotus (Walker) & 0.13 & NW/SE & $?$ & 42 \\
\hline Pteromalus varians (Spinola) & $<0.1$ & NW/SE & $?$ & 4 \\
\hline \multicolumn{5}{|l|}{ Ichneumonoidea } \\
\hline \multicolumn{5}{|l|}{ Braconidae } \\
\hline Colastes braconius (Haliday) & 0.42 & NW/SE & Idiobiont & 134 \\
\hline \multicolumn{5}{|l|}{ Ichneumonidae } \\
\hline Itoplectis alternans (Gravenhorst) & 0.2 & NW/SE & $?$ & 182 \\
\hline Scambus annulatus (Kiss) & 0.31 & NW/SE & $?$ & 79 \\
\hline
\end{tabular}

Species abundance is given as percentage of the total parasitoid complex and the location specifies the cluster assigned. Life history strategy according to Askew and Shaw (1986) and number of other host species according to Noyes (2002) for Chalcidoidea and Yu et al. (2005) for Ichneumonoidea

${ }^{a}$ A recent study has shown that $P$. mediterraneus (Ferrière and Delucchi) is not a synonym of $P$. agraules (Walker) but a closely related valid species (Gebiola et al. 2009) 


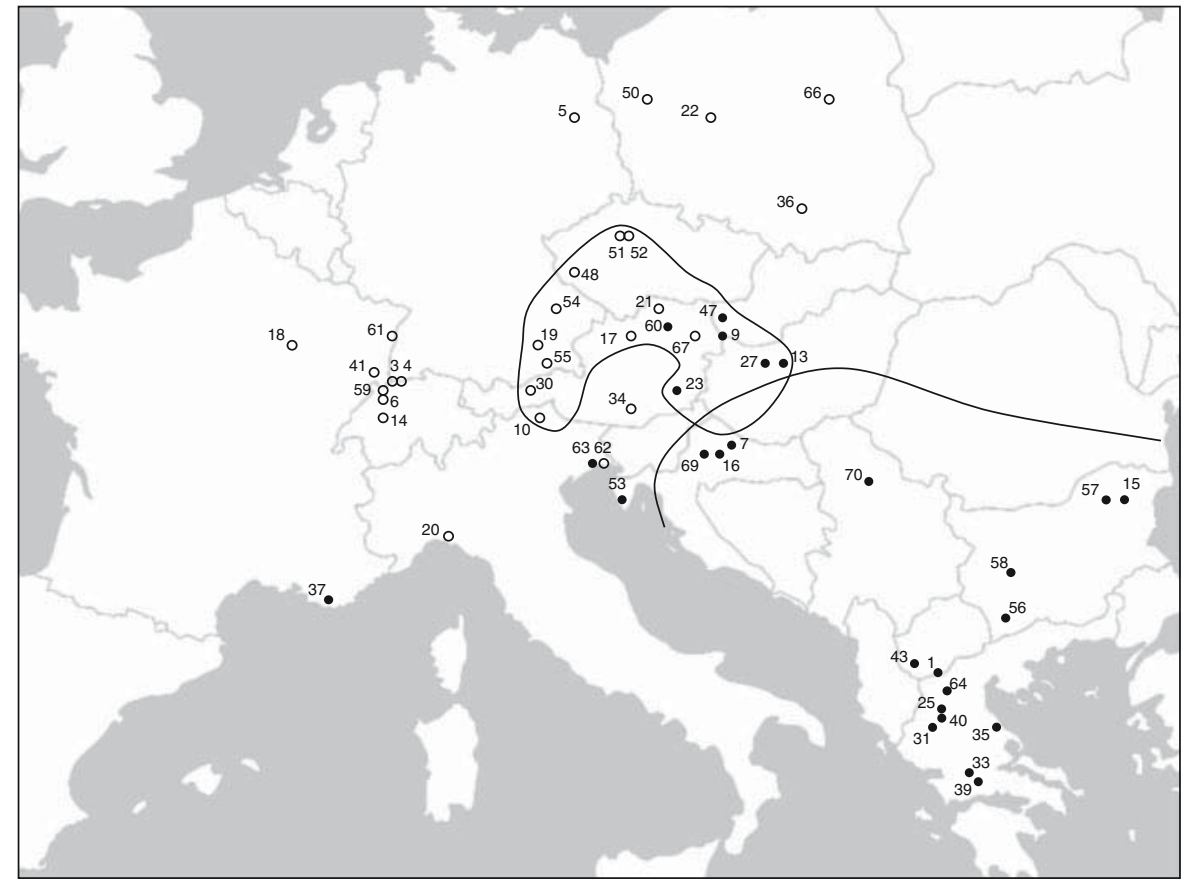

Fig. 1 Cluster analysis on the most important parasitoid species of $C$. ohridella (white dots $=\mathrm{NW}$-cluster, black dots $=\mathrm{SE}$-cluster); lines show the boarder of the two

which is known to have a narrow host range. At a first glance the parasitoid complex of $C$. ohridella in Europe seemed to be relatively uniform. 17 out of 29 parasitoid species were reared from this leafminer in the whole investigated area. However, the cluster analysis revealed striking differences in the distribution pattern of the parasitoid species. The complex was separated in a north-western and a south-eastern cluster (Fig. 1). The north-western cluster (=NWcluster) comprised most of the samples collected in northern, western and central Europe. The southeastern cluster (SE-cluster) comprised mainly those collected in south-eastern Europe. The two clusters overlapped in northern Italy and in the south and east of Austria. The mean age of the C. ohridella populations was significantly different between the two clusters (Table 2). Average host residence time in the NW-cluster was only 4.8 years while $C$. ohridella was present in the SE-cluster for more than 11 years. However, differences in species richness, species diversity and species evenness between the NW- and the SE-cluster were not significant.

The NW-cluster was characterized by the high abundance of Minotetrastichus frontalis and Pnigalio expansion waves of $C$. ohridella in 1994 (references in the text); numbers refer to location numbers given in the "Supplementary material"

Table 2 Comparison of means for host residence time, species richness, diversity and evenness of the two clusters resulting from analysis of the parasitoid complex of the leafminer (Mann-Whitney $U$-test, $n=53$ )

\begin{tabular}{lllll}
\hline & NW-cluster & SE-cluster & $z$ & Sig. \\
\hline $\begin{array}{l}\text { Host residence } \\
\text { time }\end{array}$ & $4.78 \pm 2.89$ & $11.38 \pm 5.52$ & -4.50 & $<\mathbf{0 . 0 0 1}$ \\
Species richness & $5.26 \pm 1.56$ & $6.12 \pm 1.9$ & -1.57 & 0.118 \\
Diversity & $1.01 \pm 0.24$ & $0.97 \pm 0.35$ & -0.53 & 0.594 \\
Evenness & $0.64 \pm 0.15$ & $0.54 \pm 0.15$ & -1.76 & 0.078 \\
\hline
\end{tabular}

Note: Bold $P$ values $(<0.01)$ significant

mediterraneus (Fig. 2a). These two species clearly dominated the parasitoid complex in northern, western and central Europe, whereas Pediobius saulius, Closterocerus trifasciatus and Chrysocharis nepherea were only of minor importance. Moreover, $P$. saulius, most Cirrospilus spp. and Baryscapus nigroviolaceus were only present in the southeast of the NW-cluster. The SE-cluster was dominated by $P$. saulius followed by $M$. frontalis and $C$. trifasciatus. (Fig. 2b). Compared to the NW-cluster, Cirrospilus viticola and B. nigroviolaceus were much more 
Fig. 2 Parasitoid complex of C. ohridella in a) the NW-cluster (central, western and northern Europe) and b) the SEcluster (south-eastern Europe); sectors represent the species' portion in the complex; numbers in parenthesis show the percentage of mines parasitized by the species
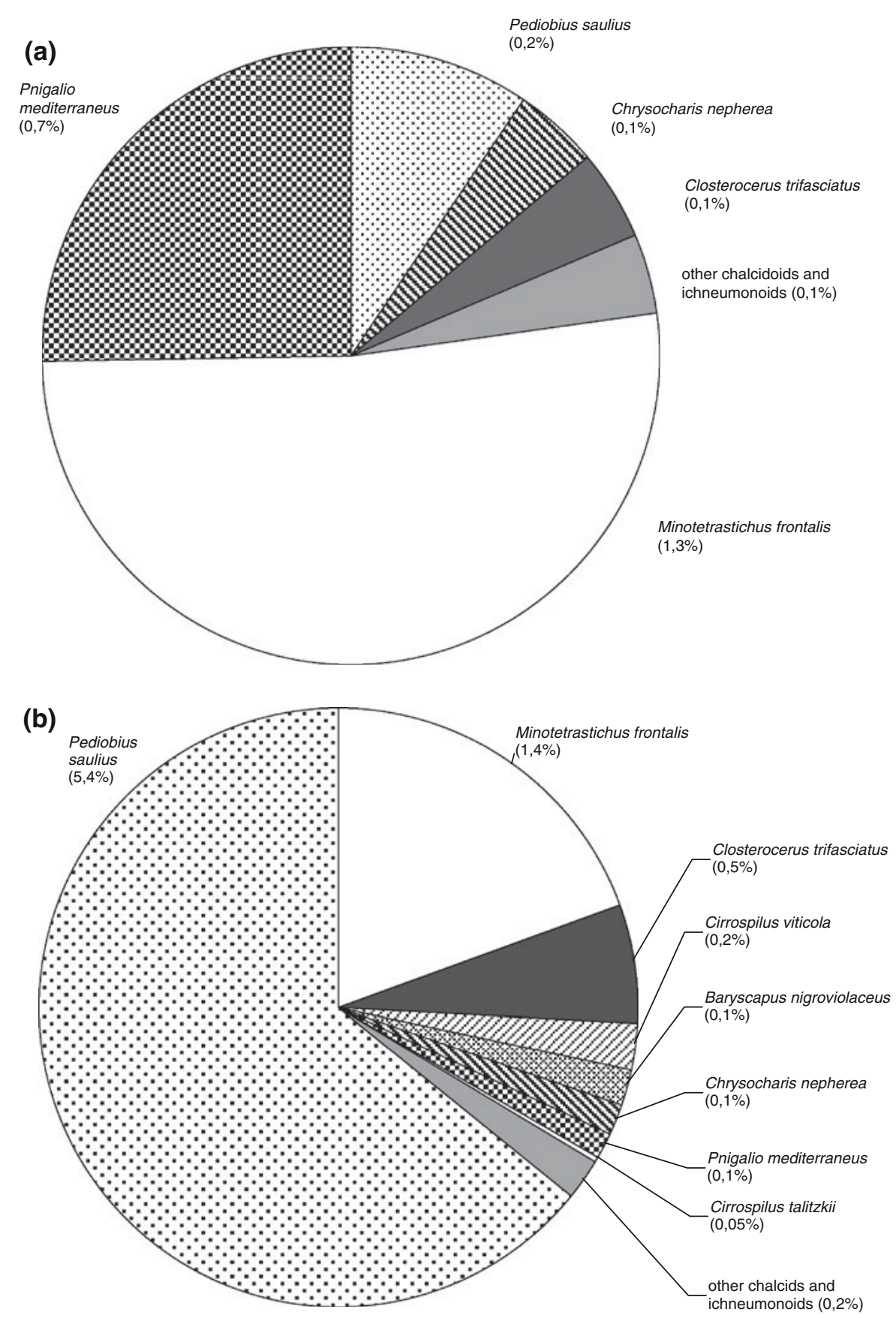

abundant while $P$. mediterraneus was almost lacking. Of particular interest was the observation of Cirrospilus talitzkii at five locations in the SE-cluster. It is the first record of $C$. talitzkii in Greece, France and Austria, and the first time it is recorded on C. ohridella in Bulgaria.
Biology of the main parasitoid species of $C$. ohridella

Pediobius saulius was the most abundant parasitoid species in this study (Table 1). Although it was rarely present in the NW-cluster, it accounted for nearly half 
of all specimens reared. $47 \%$ of the specimens identified were females. The vast majority $(97 \%)$ of this solitary endoparasitoid was reared from pupae, but a few specimens were found attacking L4 and spinning stages. $P$. saulius may also occasionally parasitize other ecto- or endo-parasitoid pupae.

Minotetrastichus frontalis was the second most abundant species in our samples, which accounted for about $30 \%$ of the parasitoids. M. frontalis was the only species found at all locations and $67 \%$ of all reared specimens were females. It parasitized the preimaginal stages L2 to Sp2, most parasitoids being on the spinning stages (Fig. 3). The species is a gregarious parasitoid, with up to ten individuals developing on a single host. Although the main part of all M. frontalis reared developed as primary parasitoids on leafminer larvae, secondary parasitism was also frequent (6\%). Larvae developed either as hyperparasitoid (i.e., the primary parasitoid was the host resource for the $M$. frontalis larvae) or as cleptoparasitoid (i.e., the larvae used hosts which had been previously paralyzed by another parasitoid species and competed successfully against the primary parasitoid larvae).

Pnigalio mediterraneus was the third most abundant parasitoid species. $63 \%$ of all specimens were females and it parasitized hosts from L2 to pupae (Fig. 3). Most larvae were found on the spinning instars of C. ohridella. P. mediterraneus never acted as a secondary parasitoid, however, its larvae were frequently parasitized by $M$. frontalis.

Closterocerus trifasciatus attacked L2 to pupae, with a distinct preference for the latter stage. It developed as a solitary endoparasitoid and often left hosts before pupation and pupated several millimeters away. $62 \%$ of all C. trifasciatus were females, and $18 \%$ developed as hyperparasitoids, mainly in pupae of ectoparasitoids.

Chrysocharis nepherea exclusively developed as a primary and solitary endoparasitoid of $C$. ohridella. The species parasitized leafminers from the L2 onwards, $57 \%$ of all offspring were females.

None of the species mentioned above showed significant differences in the proportion of females between the clusters.

Nine other species were frequently reared and their preferred host stage was unambiguously determined (Fig. 3). Of the remaining 15 parasitoid species, less than ten individuals per species were reared. Details on all parasitoid rearing results and the parasitism rates per location may be obtained from the "Supplementary material".
Fig. 3 Parasitoid-hostinteractions in the C. ohridella complex; abbreviations represent the leafminer instars as given in the "Methods" section, lines in the circles indicate the host range of the parasitoid species (thin line $=$ rarely selected as host, medium

line $=$ regularly selected as host, bold line $=$ preferred host); arrows indicate hyperparasitic relationships (thin arrows $=$ rarely observed, bold arrows $=$ regularly observed)

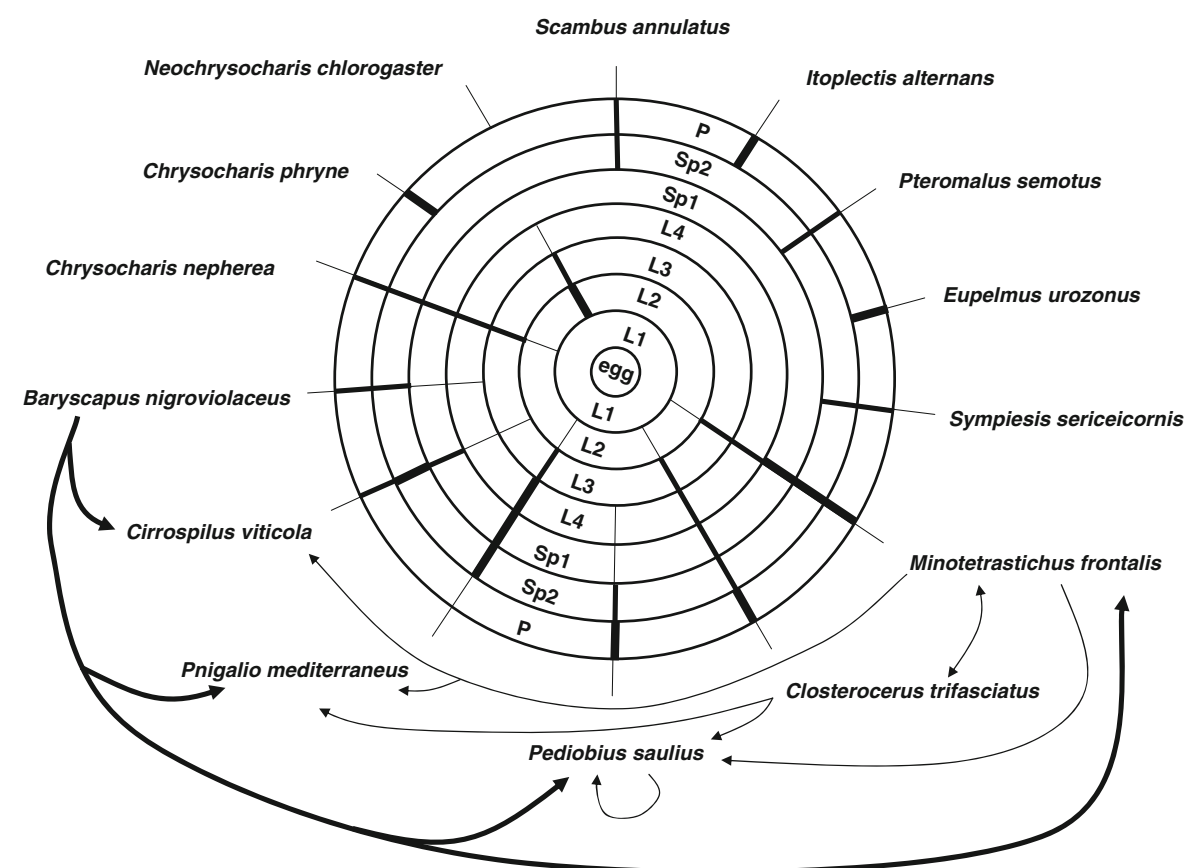




\section{Parasitism of C. ohridella}

Parasitism rates varied considerably and ranged from zero to a maximum of $33.4 \%$. The average parasitism rate was $6.2 \%$ with a standard deviation of $6.5 \%$.

The PCA-analysis on the parasitism rates of the juvenile host instars and the total parasitism rate led to two axes, explaining $74 \%$ of the variance (Table $3 \mathrm{a}$ ). The first and most important axis ( PC $\left._{\text {Plarv }}\right)$ was mainly affected by parasitism of larvae and spinning stages of C. ohridella, the second axis $\left(\mathrm{PC}_{\mathrm{Ptot}}\right)$ represented pupal and total parasitism. The second PCA was conducted on the individual parasitism of the five most important parasitoid species (Table 3b). Together, P. saulius, M. frontalis, P. mediterraneus, C. trifasciatus and C. nepherea accounted for $95 \%$ of all parasitoids reared. The three axes resulting from this PCA explained $81 \%$ of variance in parasitism of $C$. ohridella and all three axes explained nearly the same amount of variance. The parasitoid species $C$. trifasciatus and $P$. saulius were strongly correlated with the first axis $\left(\mathrm{PC}_{\mathrm{Psaul}}\right), C$. nepherea and $M$. frontalis strongly affected the second axis $\left(\mathrm{PC}_{\mathrm{Mfron}}\right)$ and $P$. mediterraneus defined the third axis $\left(\mathrm{PC}_{\mathrm{Pmed}}\right)$.

Table 3 Results of the principal component analyses

(a) PCA of percent parasitism of the juvenile stages and the total parasitism of the first generation of $C$. ohridella in spring

\begin{tabular}{|c|c|c|c|c|}
\hline & \multirow{2}{*}{$\begin{array}{l}\text { Communalities after } \\
\text { PCA-extraction }\end{array}$} & \multicolumn{2}{|c|}{ Factor loadings } & \multirow[t]{2}{*}{ Total } \\
\hline & & $\mathrm{PC}_{\text {Plarv }}$ & $\mathrm{PC}_{\text {Ptot }}$ & \\
\hline Parasitism of L1-L3 & 0.404 & 0.636 & 0.008 & \\
\hline Parasitism of L4 & 0.783 & 0.881 & 0.085 & \\
\hline Parasitism of $\mathrm{Sp} 1 / 2$ & 0.775 & 0.851 & 0.227 & \\
\hline Parasitism of pupae & 0.903 & -0.082 & 0.947 & \\
\hline Total parasitism & 0.845 & 0.394 & 0.831 & \\
\hline Variance explained (\%) & & 41.31 & 32.91 & 74.22 \\
\hline
\end{tabular}

(b) PCA of percent parasitism of the first generation of $C$. ohridella by the five most important parasitoid species in the complex

\begin{tabular}{|c|c|c|c|c|c|}
\hline & \multirow{2}{*}{$\begin{array}{l}\text { Communalities after } \\
\text { PCA-extraction }\end{array}$} & \multicolumn{3}{|c|}{ Factor loadings } & \multirow[t]{2}{*}{ Total } \\
\hline & & $\mathrm{PC}_{\text {Psaul }}$ & $\mathrm{PC}_{\text {Mfron }}$ & $\mathrm{PC}_{\text {Pmed }}$ & \\
\hline C. trifasciatus & 0.800 & 0.893 & 0.053 & 0.003 & \\
\hline P. saulius & 0.769 & 0.865 & 0.051 & -0.137 & \\
\hline C. nepherea & 0.745 & -0.063 & 0.829 & 0.230 & \\
\hline M. frontalis & 0.777 & 0.169 & 0.865 & -0.010 & \\
\hline P. mediterraneus & 0.983 & -0.095 & 0.152 & 0.975 & \\
\hline Variance explained (\%) & & 31.72 & 29.30 & 20.46 & 81.48 \\
\hline
\end{tabular}

(c) PCA on parameters describing the study sites in the survey conducted

\begin{tabular}{|c|c|c|c|c|c|}
\hline & \multirow{2}{*}{$\begin{array}{l}\text { Communalities after } \\
\text { PCA-extraction }\end{array}$} & \multicolumn{3}{|c|}{ Factor loadings } & \multirow[t]{2}{*}{ Total } \\
\hline & & $\mathrm{PC}_{\mathrm{Age}}$ & $\mathrm{PC}_{\text {Prec }}$ & $\mathrm{PC}_{\text {Temp }}$ & \\
\hline Temperature range & 0.782 & -0.884 & -0.014 & 0.000 & \\
\hline Longitude & 0.857 & 0.910 & -0.126 & 0.091 & \\
\hline $\begin{array}{l}\text { Age of } C \text {. ohridella } \\
\text { population }\end{array}$ & 0.645 & 0.747 & 0.290 & 0.056 & \\
\hline Precipitation & 0.676 & -0.398 & 0.692 & 0.197 & \\
\hline Altitude & 0.851 & 0.314 & 0.825 & -0.279 & \\
\hline Mean temperature & 0.960 & 0.008 & -0.117 & 0.973 & \\
\hline Latitude & 0.852 & -0.461 & -0.512 & -0.614 & \\
\hline Variance explained (\%) & & 37.67 & 21.94 & 20.74 & 80.35 \\
\hline
\end{tabular}

Note: Bold values indicate important factor loadings $(>0.6)$ for each factor 
The third PCA was conducted on the climatic and geographic parameters describing the sampling sites. The three axes of this PCA explained $80 \%$ of the variance in the data (Table $3 \mathrm{c})$. The first axis $\left(\mathrm{PC}_{\mathrm{Age}}\right)$ explained $38 \%$ of variance and was mainly determined by the temperature range over the year, the geographical longitude and the age of the host population. Negative values for axis one are typical for locations with a high temperature range, positive values are associated with high geographical longitudes and old host populations. Thus, the effect of the age of the host population could not be separated from the effect of climatic and geographic parameters. The second $\left(\mathrm{PC}_{\mathrm{Prec}}\right)$ and the third axis $\left(\mathrm{PC}_{\mathrm{Temp}}\right)$ each explained about $20 \%$ of variance and were therefore of equal importance. The former was affected by average precipitation and sea level (higher values indicate higher precipitation and higher sea level), and the latter by the average temperature and the geographical latitude (high values indicating high average temperatures and low latitudes).

The regression analysis revealed a poor explanatory value of the three environmental parameters for PC $_{\text {Plarv }}$ (Table 4; multiple $R^{2}=0.02, F_{3,115}=0.86$, $P$ value $=0.46)$. This indicates that the proportion of C. ohridella larvae parasitized cannot be explained by the environmental parameters included. In contrast, $\mathrm{PC}_{\mathrm{Ptot}}$ was positively affected by $\mathrm{PC}_{\mathrm{Age}}$ and $\mathrm{PC}_{\mathrm{Temp}}$.
Hence, the variance in pupal and total parasitism could partly be explained by the age of the host population, the geographic longitude and the temperature range as well as by the mean temperature and the geographic latitude (Table 4a). Analysis of leafminer parasitism by the five most important parasitoid species revealed a similar picture. The parasitism by $P$. saulius and $C$. trifasciatus $\left(\mathrm{PC}_{\mathrm{Psaul}}\right)$ was positively affected by components $\mathrm{PC}_{\mathrm{Age}}$ and $\mathrm{PC}_{\mathrm{Temp}}$ (Table 4b). Contrary, the proportion of leafminers parasitized by $M$. frontalis and C. nepherea $\left(\mathrm{PC}_{\mathrm{Mfron}}\right)$ could not be explained by the environmental parameters $\left(R^{2}=0.03, F_{3,90}=1.02, P\right.$ value $\left.=0.39\right)$ and the same was true for parasitism by $P$. mediterraneus $\left(\mathrm{PC}_{\text {Pmed }} ; R^{2}=0.07, F_{3,90}=2.34, P\right.$ value $\left.=0.08\right)$. Precipitation and altitude $\left(\mathrm{PC}_{\mathrm{Prec}}\right)$ never had a significant effect on parasitism of $C$. ohridella.

A repetition of the PCAs and regressions, excluding data of the Greek natural stands with unknown host residence time, gave similar results. Larval parasitism was not explainable with environmental parameters (multiple $R^{2}=0.09, F_{3,84}=2.62, P$ value $=0.056$ ), whereas pupal and total parasitism was partly explained by temperature, longitude and host residence time (multiple $R^{2}=0.31, F_{3,84}=11.99, P$ value $=0.00$ ). The PCA on the individual parasitism of the five most important parasitoid species resulted in two axes only. $C$. trifasciatus and $P$. saulius together affected the first axis. The second axes was strongly correlated with

Table 4 Multiple linear regression models on the eight components of Table 3

\begin{tabular}{|c|c|c|c|c|}
\hline & $\begin{array}{l}\text { Non-standardized } \\
\text { coefficients }(B \pm \mathrm{SE})\end{array}$ & $\begin{array}{l}\text { Standardized } \\
\text { coefficients }(\beta)\end{array}$ & $T$ & Significance \\
\hline \multicolumn{5}{|l|}{ (a) } \\
\hline Intercept & $-0.058 \pm 0.076$ & & -0.77 & 0.442 \\
\hline $\mathrm{PC}_{\text {Age }}$ & $0.461 \pm 0.076$ & 0.472 & 6.10 & $<0.001$ \\
\hline $\mathrm{PC}_{\text {Prec }}$ & $-0.117 \pm 0.077$ & -0.118 & -1.53 & 0.130 \\
\hline $\begin{array}{l}\mathrm{PC}_{\text {Temp }} \\
\text { (b) }\end{array}$ & $0.268 \pm 0.076$ & 0.273 & 3.53 & 0.001 \\
\hline Intercept & $-0.085 \pm 0.085$ & & -1.008 & 0.316 \\
\hline $\mathrm{PC}_{\mathrm{Age}}$ & $0.333 \pm 0.084$ & 0.370 & 3.974 & $<0.001$ \\
\hline $\mathrm{PC}_{\text {Prec }}$ & $-0.046 \pm 0.082$ & -0.052 & -0.560 & 0.577 \\
\hline $\mathrm{PC}_{\mathrm{Temp}}$ & $0.249 \pm 0.085$ & 0.274 & 2.936 & 0.004 \\
\hline
\end{tabular}

Effect of environmental parameters $\left(\mathrm{PC}_{\mathrm{Age}}, \mathrm{PC}_{\mathrm{Prec}}, \mathrm{PC}_{\mathrm{Temp}}\right)$ on (a) pupal and total parasitism of C. ohridella $\left(\mathrm{PC}_{\mathrm{Ptot}}\right)$ and (b) on parasitism of $C$. ohridella by $P$. saulius and $C$. trifasciatus $\left(\mathrm{PC}_{\mathrm{Psau}}\right)$. Bold $P$ values $(<0.01)$ significant after Bonferroni-correction (a) Multiple $R^{2}=0.31, F_{3,115}=17.39, P$ value $<0.001$, (b) Multiple $R^{2}=0.22 ; F_{3,90}=8.46, P$ value $<0.001$ 
C. nepherea and $P$. mediterraneus. $M$. frontalis was not represented appropriately by any of the axes and was therefore not included into the second regression analysis. Again, parasitism of $P$. saulius and C. trifasciatus was partly explained by the same environmental factors as pupal and total parasitism (multiple $R^{2}=0.23, F_{3,85}=8.15, P$ value $\left.=0.00\right)$, while parasitism by $P$. mediterraneus and $C$. nepherea was not explainable by any of the environmental parameters (multiple $R^{2}=0.03, F_{3,85}=0.86, P$ value $=0.47$ ).

\section{Discussion}

Native leafminers are often heavily attacked by parasitoids, and parasitism rates of more than $50 \%$ are common (e.g., Askew and Shaw 1979; Cornell and Hawkins 1993; Mey 1993). In this survey, maximum parasitism rates of little more than $30 \%$ have been observed only occasionally and our study's average parasitism rate of $6.2 \%$ corresponds to previously recorded parasitism rates of $C$. ohridella (Freise et al. 2002; Girardoz et al. 2006; Grabenweger and Lethmayer 1999; Volter and Kenis 2006). Other introduced leafminers tend to be more heavily parasitized by native parasitoids than $C$. ohridella. Girardoz et al. (2007c) compared sympatric parasitoid complexes of three alien Gracillariidae in Europe, C. ohridella, Phyllonorycter robiniella and P. platani. Although parasitoid richness was roughly similar, parasitism rates were significantly lower in C. ohridella than in the two Phyllonorycter species. Phyllonorycter leucographella and P. platani reached parasitism rates of 56.6 and $37.5 \%$, respectively, $<10$ years after their introduction into the UK (Godfray et al. 1995).

The low parasitism rates of $C$. ohridella have previously been used to demonstrate the lack of adaptation of native parasitoids to this introduced host (Girardoz et al. 2007c; Grabenweger 2004; Grabenweger et al. 2005a). In our survey, however, first evidence for such an adaptation was detectable in several parasitoid species. Whereas larval parasitism was not influenced by any of the investigated parameters, pupal and total parasitism were influenced by geographic and climatic parameters as well as by the age of the host population. The relative importance of the latter deserves closer attention when searching for signs of adaptation. Gröbler and
Lewis (2008) studied the parasitism of P. leucographella during its range expansion in the UK. They found declining parasitoid richness as well as parasitism rates from south to north and suggested this to be either correlated with increasing geographic latitudes or decreasing host residence times. However, they considered the former to be more important, among other reasons because of fast host switches in some parasitoids, the low host specificity of the examined parasitoid complex in general and the fact that species richness gradients with latitude had already been demonstrated before (Noyes 1989). Menéndez et al. (2008) also found declining parasitism rates in the butterfly Aricia agestis (Denis and Schiffermüller) with increasing latitudes and decreasing host residence times in the UK. In contrast to Gröbler and Lewis (2008), however, parasitism richness did not show the same trend and closely related native butterflies were heavily attacked at the newly colonized northern boundaries of the range of A. agestis. The low parasitism levels were therefore not the result of latitudinal patterns of parasitoid richness or abundance, since the parasitoids were already present in the newly colonized area. Rather, the parasitoids were unable to use the novel host resource as a consequence of behavioral or biological incompatibilities, which they may, however, overcome with increasing host residence time. The results of our study point in the same direction. The parasitoid complex of $C$. ohridella is similar to that of native leafminers, all but one of the 29 species recorded are known for their Palaearctic or at least pan-European distribution and their occurrence on many other leafmining hosts (Noyes 2002). Geographic or climatic constraints are therefore considered to be less important than the age of the host population. Moreover, longitude and temperature range are correlated with host residence time because outbreaks started in south-eastern Europe with a ponto-mediterranean climate and spread to cooler regions in central and north-western Europe. We therefore believe that increasing rates of pupal and total parasitism reflect the historic spread of the horse chestnut leafminer, while constant rates of larval parasitism do not. Regression results with the five most important parasitoid species support this hypothesis. Parasitism rates of the predominantly pupal parasitoids $P$. saulius and $C$. trifasciatus could partly be explained by host residence time and 
environmental factors, but these variables did not affect the parasitism by $M$. frontalis, C. nepherea and $P$. mediterraneus, the three most important larval parasitoids of $C$. ohridella. A repetition of the analyses excluding data from Greek natural stands, where host populations may be significantly older than estimated, gave similar results. It is therefore assumed that the adaptations leading to increased pupal parasitism and to increased parasitism by $P$. saulius and $C$. trifasciatus have been accomplished in recent times, probably within a time period of about two decades.

The cluster analysis on the parasitoid community of $C$. ohridella in Europe revealed two distinct parasitoid complexes. The NW-cluster combines locations in central, northern and western Europe, whereas the SE-cluster comprises mostly samples from southeast Europe. A major difference between the NW- and SE-cluster was the period of C. ohridella's presence. The average host residence time in the "younger" NW-cluster was about 5 years, while it was at least 11 years in the "older" SE-cluster. However, diversity and evenness of the parasitoid species were not significantly different between the two clusters, although parasitism rates were about twice as high in the latter. This significant difference is primarily explained by the greater abundance of a single species, the pupal parasitoid $P$. saulius.

The position of the border between the NW- and SE-cluster is of particular interest. It corresponds to the line where the two waves of $C$. ohridella invasion met in 1993/1994 (see Fig. 1). This suggests that the parasitoid complex of the NW-cluster is based on the accidental introduction of the leafminer into Austria in 1989. In this region, $C$. ohridella established after long-distance human transport (see Gilbert et al. 2004) and parasitoids from other regions could not accumulate in the course of the host's spread, as postulated in the "geographic spread hypothesis" (Cornell and Hawkins 1993). In addition, the short residence time strongly limited parasitoids' chances for behavioral, phenological or biological adjustment, prerequisites for the increase of parasitoid richness in the "adjustment-hypothesis". Abundant parasitoids in the NW-cluster are therefore species native to this region, which were able to expand their host range with only minor needs for behavioral, phenological or biological adjustment. A good example of such a parasitoid is $M$. frontalis. It is the only parasitoid present at all locations, irrespective of host residence time. In contrast to the suggestions of Klug et al. (2008), the main part of the $M$. frontalis reared during this study developed as primary parasitoids of C. ohridella larvae, even in leafminer populations which had established only 1 year before sample collection. The immediate adoption of $C$. ohridella by $M$. frontalis is therefore an impressive example for behavioral flexibility. Probably, this idiobiont species searches for hosts on virtually any available tree in the environment, which may be very effective for generalist parasitoids (Godfray et al. 1995). However, our results also suggest that parasitism by $M$. frontalis did not increase with the leafminers' residence time indicating a lack of further adaptation.

The development of the parasitoid complex of the SE-cluster seems to be different to that described previously. There, C. ohridella expanded its range naturally and the accumulation of parasitoid species occurred over a minimum period of two decades (see Simova-Tošić and Filev 1985). Abundant parasitoids may therefore have encountered their new host during its geographic spread and had more time for adjustment to the host's phenological, behavioural or biological characteristics. The parasitism pattern of $P$. saulius seems to be an example for the latter mechanism, since this species dominated the southeastern parasitoid complex of $C$. ohridella, while it was almost absent in the NW-cluster. Interestingly, it is a common parasitoid of other leafminers in northwestern Europe (Bouček 1965; Noyes 2002). The increasing importance of this species indicates that a more specialized strain of $P$. saulius evolved in the SE-cluster as a consequence of successful biological, behavioral or phenological adaptations to the new host resource. However, there is another possible explanation for the success of this species, which cannot be excluded at the present state of knowledge. In the light of recent taxonomical studies based on molecular genetics many presumed generalist parasitoid species turn out to be a complex of cryptic species which may have narrower host ranges than previously estimated. This has already been shown for tachinid flies (Smith et al. 2006, 2007) as well as for parasitic hymenoptera (Bernardo et al. 2008; Smith et al. 2008), and has already been supposed for $P$. saulius attacking $C$. ohridella by Girardoz et al. (2007c). Therefore, the "adjustment" of $P$. saulius to $C$. ohridella has to remain 
hypothetical until the taxonomic status of this parasitoid species and its proper host range have been clarified by additional molecular and behavioral studies.

Aside from these taxonomical uncertainties, host records from previous surveys provide evidence that a strain or a sibling species of $P$. saulius from southeast Europe followed the spread of $C$. ohridella after its local adaptation, supporting our regression results (Table 4). In Austria, the species was absent in the complex of the horse chestnut leafminer until 1996 (Deschka 1995; Pschorn-Walcher 1997; Stolz 1997) and appeared in low numbers for the first time only in 1997 (Grabenweger and Lethmayer 1999; Stolz unpublished data), about 3 years after the two waves of invasion of $C$. ohridella had merged at the southeastern borders of Austria (Fig. 1). In the current study, $P$. saulius was one of the most abundant parasitoids found at these locations. Torchin et al. (2003) showed that parasitoids following the invasions of their host achieve similar importance in invading and original host populations. The importance of $P$. saulius is therefore expected to increase at least on a spatial scale.

Cirrospilus talitzkii provides an example of a parasitoid that may have been added to the parasitoid complex of $C$. ohridella during its spread, supporting the "geographic spread-hypothesis" by Cornell and Hawkins (1993). Prior to the invasion of the horse chestnut leafminer, C. talitzkii was only known from Asia and east Europe (Noyes 2002). During this study, however, we reared this species from $C$. ohridella in Greece, Bulgaria, Austria and France. Recently, it was also recorded in the parasitoid complex of $C$. ohridella in Italy (Radeghieri et al. 2002). Probably, C. talitzkii followed the spread of the newly encountered host, and thus contributes not only to a local parasitoid complex, but also to parasitoid richness on a larger spatial scale. As well as for $P$. saulius (and virtually any parasitoid of the complex), only a molecular phylogeographic analysis could definitely prove the recent spread of $C$. talitzkii in the wake of the horse chestnut leafminer. However, the records of C. talitzkii developing on C. ohridella larvae were the first records of this species in all the above mentioned countries ever, except Bulgaria. This is in strong contrast to the other parasitoid species of $C$. ohridella, which are all common throughout Europe, and thus a strong support for our hypothesis.
A complex of 29 mostly idiobiont species with a broad host range, as found in this study, resembles the complexes of native European leafminers, which are generally dominated by idiobionts (among others Askew and Shaw 1974; Cornell and Hawkins 1993; Hawkins and Lawton 1987; Hellrigl 2001; Noyes 2002). Nevertheless, parasitoid complexes of closely related leafminers usually also comprise a limited number of koinobionts with a narrow host range, such as species of the genus Achrysocharoides (Askew and Shaw 1986). Four parasitoids found in our study, namely P. saulius, Elachertus inunctus, Neochrysocharis chlorogaster and Chrysocharis phryne, are known to be koinobionts (Askew and Shaw 1986). The idiobionts/koinobiont ratio in our study is therefore high but not unusual in leafminers (see Askew and Shaw 1974). However, none of the koinobionts found here is known to have a narrow host range, although the existence of sibling species with narrower host ranges cannot be excluded (see "Discussion" previously). Shaw (1994) pointed out that life history strategies are generally correlated with host specificity in large comparative studies but that there is also large variation in host specificity within both idiobionts and koinobionts. Godfray et al. (1995) did not rely on idiobiont/koinobiont ratios alone but also explored the host ranges of the parasitoid species that had been recruited by the two invasive Phyllonorycter species. Both of their analyses did not reveal any differences between the parasitoid complexes of the invaders and native leafminers. In our study, however, the host range of the koinobionts recruited by $C$. ohridella is very large and more specialized parasitoid species are completely lacking (see Table 1). The explanatory power of the idiobiont/koinobiont ratio in the examined complex is therefore rather limited.

In conclusion, our results suggest that the parasitism of $C$. ohridella in Europe tends to increase with host residence time. We found first signs of adaptation of some parasitoids in the sense of the "adjustment" hypothesis as well as evidence for a parasitoid accumulation in the course of the geographic spread of C. ohridella. However, both mechanisms of parasitoid recruitment were mainly observed in regions with old host populations. Thus, a minimum period of at least two decades of host residence time seemed to be needed for a basic adaptation of native parasitoids to this novel host. To the present state of 
knowledge, koinobionts with a narrow host range are absent even in the oldest $C$. ohridella populations, which shows the rudimentary developmental stage of this parasitoid complex. We therefore believe that further changes in the parasitoid complex of C. ohridella are to be expected. A continuous monitoring of this host parasitoid association may therefore reveal novel insights in the adaptation of natural enemies to invading hosts, which may hence lead to a more profound understanding of the secret of success of invaders.

Acknowledgments Many thanks go to colleagues from different European countries for providing additional leaf samples for this analysis: Andrea Nardini, Trieste (I), Barbara Jäckel, Berlin (D), Zoltan Kovacs, Sopron (HU), Boris Hrasovec, Zagreb (HR), Marius Gilbert, Brussels (BE), Vitaliy Kryvoruchko, Vienna (A), Krzysztof Wieczorek, Vienna (A), Ivo Holy, Prague (CZ). The parasitoids found in this study were determined by the senior author, nevertheless his expertise derived from the help of many taxonomists in previous investigations, i.e., Stefan Vidal, Göttingen (D), Hannes Baur, Bern (CH), Richard Askew, Beeston (UK), Christer Hansson, Lund (S), Csaba Thuroczy, Köszeg (H). We are also very grateful to Laura Parsons and David C. Lees, London (UK) for proofreading the English and to two anonymous referees for their valuable comments which helped to improve an earlier version of the manuscript. This study was financially supported by the European Commission and the Swiss Federal Office for Education and Science as part of the FP5 project CONTROCAM, QLK5-CT-2000-01684.

\section{References}

Askew RR, Shaw MR (1974) An account of the Chalcidoidea parasitising leaf mining insects of deciduous trees in Britain. Biol J Linn Soc 6:289-335

Askew RR, Shaw MR (1979) Mortality factors affecting the leaf-mining stages of Phyllonorycter (Lepidoptera: Gracillariidae) on oak and birch. 1. The analysis of the mortality factors. Zool J Linn Soc 67(1):31-49

Askew RR, Shaw MR (1986) Parasitoid communities: their size, structure and development. In: Waage J, Greathead $\mathrm{D}$ (eds) Insect parasitoids-13th symposium of the royal entomological society of London. Academic Press, London, pp 225-271

Bernardo U, Monti MM, Nappo AG, Gebiola M, Russo A, Pedata PA, Viggiani G (2008) Species status of two populations of Pnigalio soemius (Hymenoptera: Eulophidae) reared from two different hosts: an integrative approach. Biol Control 46:293-303

Blumenthal D (2005) Interrelated causes of plant invasion. Science 310:243-244
Bouček Z (1965) Studies on European Eulophidae, IV: Pediobius (Walker) and two allied genera (Hymenoptera). Acta Entomol Musei Nationalis Pragae 36:5-90

Callaway RM, Aschehoug ET (2000) Invasive plants versus their new and old neighbours: a mechanism for exotic invasion. Science 290:521-523

Colautti RI, Ricciardi A, Grigorovich IA, MacIsaac HJ (2004) Is invasion success explained by the enemy release hypothesis? Ecol Lett 7:721-733

Cornell HV, Hawkins BA (1993) Accumulation of native parasitoid species on introduced herbivores: a comparison of hosts as natives and hosts as invaders. Am Nat 141(6):847-865

Deschka G (1995) Beitrag zur Populationsdynamik der Cameraria ohridella Deschka \& Dimić (Gracillariidae, Lepidoptera, Chalcididae, Ichneumonidae, Hymenoptera). Linzer biol Beitr 27(1):255-258

Deschka G, Dimić N (1986) Cameraria ohridella sp. n. aus Mazedonien, Jugoslawien (Lepidoptera; Lithocolletidae). Acta Entomol Jugosl 22(1-2):11-23

Freise J, Heitland W (2004) Bionomics of the horse-chestnut leaf miner Cameraria ohridella Deschka \& Dimić 1986, a pest on Aesculus hippocastanum in Europe (Insecta, Lepidoptera, Gracillariidae). Senckenbergiana biologica 84:61-80

Freise J, Heitland W, Tosevski I (2002) Parasitism of the horse chestnut leafminer, Cameraria ohridella Deschka and Dimić (Lep., Gracillariidae), in Serbia and Macedonia. J Pest Sci 75:152-157

Gebiola M, Bernardo U, Monti MM, Navone P, Viggiani G (2009) Pnigalio agraules (Walker) and P. mediterraneus Ferrière \& Delucchi (Hymenoptera: Eulophidae): two closely related valid species. J Nat Hist 43:2465-2480

Gilbert M, Gregoire J-C, Freise JF, Heitland W (2004) Longdistance dispersal and human population density allow the prediction of invasive patterns in the horsechestnut leafminer Cameraria ohridella. J Anim Ecol 73:459-468

Gilbert M, Guichard S, Freise J, Gregoire J-C, Heitland W, Straw N, Tilbury C, Augustin S (2005) Forecasting Cameraria ohridella invasion dynamics in recently invaded countries: from validation to prediction. J Appl Ecol 45:805-813

Girardoz S, Kenis M, Quicke D (2006) Recruitment of native parasitoids by an exotic leafminer, Cameraria ohridella: host-parasitoid synchronization and influence of the environment. Agric For Entomol 8:49-56

Girardoz S, Quicke DLJ, Kenis M (2007a) Factors favouring the development and maintenance of outbreaks in an invasive leaf miner Cameraria ohridella (Lepidoptera: Gracillariidae): a life table study. Agric For Entomol 9:141-158

Girardoz S, Tomov R, Eschen R, Quicke DLJ, Kenis M (2007b) Two methods assessing the mortality factors affecting larvae and pupae of Cameraria ohridella in the leaves of Aesculus hippocastanum in Switzerland and Bulgaria. Bull Entomol Res 97:445-453

Girardoz S, Volter L, Tomov R, Quicke DLJ, Kenis M (2007c) Variations in parasitism in sympatric populations of three invasive leaf miners. J Appl Entomol 131:603-612 
Godfray HCJ, Agassiz DJL, Nash DR, Lawton JH (1995) The recruitment of parasitoid species to two invading herbivores. J Anim Ecol 64:393-402

Grabenweger G (2004) Poor control of the horse chestnut leafminer, Cameraria ohridella (Lepidoptera: Gracillariidae), by native European parasitoids: a synchronisation problem. Eur J Entomol 101:189-192

Grabenweger G, Grill R (2000) On the place of origin of Cameraria ohridella Deschka \& Dimic (Lepidoptera: Gracillariidae). Beitr Entomofaunistik 1:9-17

Grabenweger G, Lethmayer C (1999) Occurence and phenology of parasitic Chalcidoidea on the horse chestnut leafminer Cameraria ohridella Deschka \& Dimić (Gracillariidae, Lepidoptera). J Appl Entomol 123:257-260

Grabenweger G, Stolz M, Jeziorny C (2003) A key to the parasitoids of Cameraria ohridella (Lep., Gracillariidae). CD-ROM published privately via The Natural History Museum, Vienna

Grabenweger G, Avtzis N, Girardoz S, Hrasovec B, Tomov R, Kenis M (2005a) Parasitism of Cameraria ohridella (Lepidoptera, Gracillariidae) in natural and artificial horse-chestnut stands in the Balkans. Agric For Entomol 7(4):291-296

Grabenweger G, Kehrli P, Schlick-Steiner B, Steiner F, Stolz M, Bacher S (2005b) Predator complex of the horse chestnut leafminer Cameraria ohridella: identification and impact assessment. J Appl Entomol 129:353-362

Gröbler BC, Lewis OT (2008) Response of native parasitoids to a range-expanding host. Ecol Entomol 33:453-463

Gurevitch J, Padilla DK (2004) Are invasive species a major cause of extinctions? Trends Ecol Evol 19:470-474

Hawkins BA, Lawton JH (1987) Species richness for parasitoids of British phytophagous insects. Nature 326:788-790

Heitland W, Kopelke J, Freise J, Metzger J (1999) Ein Kleinschmetterling erobert Europa-die RosskastanienMiniermotte Cameraria ohridella. Natur und Museum 129:186-195

Heitland W, Freise J, Sturm A, Lenz N (2005) Die Rosskastanien-Miniermotte, Cameraria ohridella Deschka \& Dimić, 1986 (Lepidoptera, Gracillariidae): Gründe ihres Erfolgs als Blattschädling an der weißblühenden Gewöhnlichen Rosskastanie Aesculus hippocastanum (Hippocastanaceae) und Möglichkeiten zur Bekämpfung. Entomologie heute 17:157-172

Hellrigl K (2001) Neue Erkenntnisse und Untersuchungen über die Roßkastanien-Miniermotte Cameraria ohridella Deschka \& Dimić, 1986 (Lepidoptera, Gracillariidae). Gredleriana 1:9-81

Holzschuh C (1997) Woher kommt die Roßkastanienminiermotte wirklich? Forstschutz Aktuell 21:11-12

Hooper DU, Chapin FS, Ewel JJ, Hector A, Inchausti P, Lavorel S, Lawton JH, Lodge DM, Loreau M, Naeem S, Schmid B, Setala H, Symstad AJ, Vandermeer J, Wardle DA (2005) Effects of biodiversity on ecosystem functioning: a consensus of current knowledge. Ecol Monogr 75:3-35

Keane RM, Crawley MJ (2002) Exotic plant invasions and the enemy release hypothesis. Trends Ecol Evol 17:164-170

Kenis M, Tomov R, Svatos A, Schlinsog P, Lopez Vaamonde C, Heitland W, Grabenweger G, Girardoz S, Freise J, Avtzis N (2005) The horse-chestnut leaf miner in Europe. Prospects and constraints for biological control. In:
Hoddle M (ed) Proceedings of the 2nd international symposium on biological control of arthropods, Davos, Switzerland, 12-16 September 2005, Forest Health Technology Enterprise Team, Morgantown, pp 77-90

Klug T, Meyhöfer R, Kreye M, Hommes M (2008) Native parasitoids and their potential to control the invasive leafminer, Cameraria ohridella DESCH. \& DIM. (Lep.: Gracillariidae). Bull Entomol Res 98:379-387

Menéndez R, González-Megías A, Lewis OT, Shaw MR, Thomas CD (2008) Escape from natural enemies during climate-driven range expansion: a case study. Ecol Entomol 33:413-421

Mey W (1993) Zur Parasitierung der Pfennigminiermotte, Leucoptera malifoliella (Costa), (Lepidoptera, Lyonetiidae) im Havelländischen Obstbaugebiet. J Appl Entomol 115:329-341

Mitchell CE, Power AG (2003) Release of invasive plants from fungal and viral pathogens. Nature 421:625-627

Noyes J (1989) The diversity of Hymenoptera in the tropics with special reference to Parasitica in Sulawesi. Ecol Entomol 14:197-207

Noyes J (2002) Interactive catalogue of world Chalcidoidea. CD-ROM, Taxapad, Vancouver

Pschorn-Walcher H (1997) Zur Biologie und Populationsentwicklung der eingeschleppten Roßkastanien-Miniermotte, Cameraria ohridella. Forstschutz Aktuell 21:7-10

Puchberger KM (1995) Zur Geschichte der ersten Ausbreitung von Cameraria ohridella Deschka \& Dimić 1986 in Österreich (Lepidoptera, Gracillariidae). Entomol Nachrichtenblatt 1:2-3

Quicke DLJ (1997) Parasitic wasps. Chapman and Hall, London

Radeghieri P, Santi F, Maini S (2002) New record species for the Italian fauna: Cirrospilus talitzkii (Hymenoptera Eulophidae), a new parasitoid of Cameraria ohridella (Lepidoptera Gracillariidae) (Preliminary note). Bull Insectol 55(1-2):63-64

Šefrová H, Laštůvka Z (2001) Dispersal of the horse-chestnut leafminer, Cameraria ohridella Deschka \& Dimic, 1986, in Europe: its course, ways and causes (Lepidoptera: Gracillariidae). Entomol Z 111(7):194-198

Shaw MR (1994) Parasitoid host ranges. In: Hawkins BA, Sheehan W (eds) Parasitoid community ecology. Oxford University Press, Oxford, pp 112-144

Shea K, Chesson P (2002) Community ecology theory as a framework for biological invasions. Trends Ecol Evol 17:170-176

Simova-Tošić D, Filev S (1985) Contribution to the horse chestnut miner. Zaštita bilja 36(3):235-239

Smith MA, Woodley N, Hallwachs W, Janzen DL, Hebert PDN (2006) DNA barcodes reveal cryptic host-specificity within the presumed polyphagous members of a genus of parasitoid flies (Diptera: Tachinidae). Proc Natl Acad Sci 103(10):3657-3662

Smith MA, Wood DM, Janzen DL, Hallwachs W, Hebert PDN (2007) DNA barcodes affirm that 16 species of apparently generalist tropical parasitoid flies (Diptera, Tachinidae) are not all generalists. Proc Natl Acad Sci 104(12):4967-4972

Smith MA, Rodriguez J, Whitfield J, Deans A, Janzen DL, Hallwachs W, Hebert PDN (2008) Extreme diversity of tropical parasitoid wasps exposed by iterative integration 
of natural history, DNA barcoding, morphology and collections. Proc Natl Acad Sci 105(34):12359-12364

Stolz M (1997) Untersuchungen über Larval- und Puppenparasitoide von Cameraria ohridella in Hinblick auf ihre Eignung zur Laborzucht. Forstschutz Aktuell 21:31

Thalmann C, Freise J, Heitland W, Bacher S (2003) Effects of defoliation by horse chestnut leafminer (Cameraria ohridella) on reproduction of Aesculus hippocastanum. Trees Struct Funct 17:383-388

Tomiczek C, Krehan H (1998) The horsechestnut leafmining moth (Cameraria ohridella): a new pest in central Europe. J Arboric 24(3): 144-148

Torchin ME, Lafferty KD, Dobson AP, McKenzie VJ, Kuris AM (2003) Introduced species and their missing parasites. Nature 421:628-630

Valade R, Kenis M, Hernandez-Lopez A, Augustin S, Mari Mena N, Magnoux E, Rougerie R, Lakatos F, Roques A, Lopez Vaamonde C (2009) Mitochondrial and microsatellite DNA markers reveal a Balkanic origin for the highly invasive Horse-Chestnut leaf miner Cameraria ohridella (Lepidoptera, Gracillariidae). Mol Ecol 18:3458-3470

Volter L, Kenis M (2006) Parasitoid complex and parasitism rates of the horse chestnut leafminer, Cameraria ohridella (Lepidoptera: Gracillariidae) in the Czech Republic, Slovakia and Slovenia. Eur J Entomol 103:365-370

Washington HG (1984) Diversity, biotic and similarity indices-a review with special relevance to aquatic ecosystems. Water Resour 18:653-694

Xiang QY, Crawford DJ, Wolfe AD, Tang YC, De Pamphilis CW (1998) Origin and biogeography of Aesculus L. (Hippocastanaceae): a molecular phylogenetic perspective. Evolution 52(4):988-997

Yu D, van Achterberg K, Horstmann K (2005) World Ichneumonoidea 2004. Taxonomy, biology, morphology and distribution. CD-ROM, Taxapad, Vancouver 